\title{
Governance of climate adaptation, which mode? An exploration of stakeholder viewpoints on how to organize adaptation
}

\author{
Astrid Molenveld $^{1,2}$ (D) Arwin van Buuren ${ }^{1} \cdot$ Gerald-Jan Ellen $^{3}$
}

Received: 3 September 2019 / Accepted: 19 February 2020 / Published online: 17 June 2020

(C) The Author(s) 2020

\begin{abstract}
There are many normative answers on the question how to realize climate adaptation, ranging from pleas for the government to play a decisive role, to calls for refraining from action and relying upon spontaneous adaptation of both government and nongovernmental actors. In this article, we present a Q methodological study, aimed at investigating the governance preferences among non-governmental actors in the Netherlands and the "narratives" they use to motivate these preferences. Our empirical results underline the fact that the question "how to organize adaptation", is a controversial one. The results resemble the various positions in the current academic debate about the governance of adaptation, and add important insights and nuances to it. Many respondents feel that the current climate adaptation policy is too non-committal. The dominant viewpoint underscores a need for more rules and norms and the possibility to sanction organizations that do not adapt. Minority viewpoints show an urge to stimulate and support self-organization of partners, as well as a need for more action. However, financial and regulatory preconditions are needed to stimulate actors in order to see to the necessary investments. Policy-makers have to invest in mixing their policy instruments. Clearly, most nongovernmental actors are in favor of the government setting a framework with rules and norms for climate adaption. However, the viewpoints show that this is not sufficient. The government should facilitate networks, joint efforts and create the financial and regulatory preconditions to remove current barriers blocking adaptation measures.
\end{abstract}

Keywords Climate adaptation · Stakeholder perspectives · Governance $\cdot$ Q methodology

Astrid Molenveld

molenveld@essb.eur.nl

1 Department of Public Administration and Sociology, Erasmus Universiteit Rotterdam, Rotterdam, The Netherlands

2 Research Group on Politics \& Public Governance, University of Antwerp, Antwerpen 2000, Belgium

3 Deltares, Delft, Netherlands 


\section{Introduction}

The increasing evidence of the various impacts of climate change urges governments to think not only about mitigation programs in order to reduce $\mathrm{CO}_{2}$ emissions but also to formulate adaptation strategies in order to cope with the consequences. At the same time, many scholars claim that governance of climate change is a "wicked" (Alford and Head 2017) or even "a super wicked" (Lazarus 2008) problem. This "wickedness" implies not only a lack of consensus about (scientific) knowledge of the (potential and impact of the) effects of climate change and about (the consequences of) solutions for the problem, it also means there are highly divergent viewpoints about the strategy on how to solve the issue with the actors involved (Hulme 2009; Verweij et al. 2006). Because of the latter, governments struggle and are bound to processes of extensive participation in order to find a consensus about joint action (Alford and Head 2017; Biesbroek et al. 2010). Given the highly interactive and wicked nature of the issue, scholars often ask themselves: what kind of government action and which type of governance is needed to coordinate climate adaptation (Huitema et al. 2016; Mees et al. 2013)?

Bovaird and Löffler $(2009,8)$ state: "trying to define public governance seems to open Pandora's box". They define public governance as how an organization works with its partners, stakeholders, and networks to influence the outcomes of public policies (p. 6). This "how" can be highly different. In the literature, many contributions reflect upon typologies, and distinguish different forms of governance and their relative merits and disadvantages (Bouckaert et al. 2010; Considine and Lewis 1999, 2003; Dixon and Dogan 2002; Lowndes and Skelcher 1998; Powell 1990; Thompson et al. 1991). The scholars agree that these typologies, such as hierarchy, market, and networks, are ideal types and should be studied with care as most of the governance arrangements are mixed types (Tenbensel 2018). Second, scholars also say policy-makers mix styles in order to be effective and appeal to a broad array of actors (Keast et al. 2007; Voets et al. 2015). Designing the most effective and efficient policy instrument mix is a challenge, but an essential task for policy-makers (Howlett 2009), especially when it comes to policy issues that are highly wicked. Various scholarly contributions study forms of governance that can be applied in order to achieve climate adaptation (Henstra 2016). However, a more empirical investigation of the 'governance preferences' of those subjected to government action seems to be lacking.

This paper therefore undertakes the task to study these preferences among Dutch nongovernmental stakeholders. Non-governmental or non-public actors, like NGOs, housing corporations, nature conservation organizations, societal interest groups, private companies, and consultancy firms, play a major role in the climate change arena, not only because they are the ones who advise on the issues and implement climate adaption measures, but also because their interests influence the controversial climate adaptation debate. Their perspective is highly relevant, not only because they face the consequences of climate change and ask for governmental action, but they are also stakeholders directly affected by government policy regarding adaptation measures. How do they perceive the way in which the climate adaptation policy is governed and how this plays out, and what governance approach is fruitful, according to them, in the future? Assisted by Q methodology — a method to study commonalities and differences in a particular policy community by means of factor analyses - we unravel the dominant viewpoints on climate adaptation governance in the Netherlands. This methodology helps to highlight the significant areas of conflict and consensus in the climate adaptation debate, by pointing out the main issues of difference and similarity. Thus, we aim to answer these research questions: 
RQ1: What are the viewpoints on climate adaptation governance among non-governmental stakeholders?

RQ3: How do these viewpoints relate to the literature on climate adaptation governance?

RQ3: What lessons can we discern from the different viewpoints on climate adaptation governance?

In the following paragraphs, we explore different modes of governance, based on the scholarly literature, and attempt to situate the current governance approach of the climate adaptation issue in the Netherlands. In the section thereafter, the methodology is explained. In the remainder of this paper, the results are discussed, and we end the paper with a concluding paragraph in which we compare our findings with the literature on the governance of climate adaptation and policy recommendations.

\section{Modes of governance}

The way in which public issues are governed by government is discussed in scholarly literature by using different labels. Some authors refer to governance modes or mechanisms (Considine 2001; Howlett 2009; Lowndes and Skelcher 1998; Williamson 1996). Other authors use the term policy instruments to describe instruments that steer public action (Hall 2011; Salamon 2002). The idea of steering modes departs from the idea that governments can use different types of approaches and strategies (Bouckaert et al. 2010; Powell 1990) that rely upon the logic of (1) the state (and the formal legal power it possesses); (2) the market (and thus upon financial incentives and solutions that uses market-like mechanisms); or (3) the networks (collaboration and mutual adjustment, dialog etc.) (Lowndes and Skelcher 1998), as the set of institutions that is intended to foster coordination of actions in the public domain.

Realizing coordinated action to reach climate adaptation has to do with applying a deliberated mixture of different modes of governance, policy instruments, and management strategies (Molenveld et al. 2020; Bouckaert et al. 2010; Powell 1990). The classical way of implementing policy is by means of hierarchical or legal governance. In this mode of governance, steering is conducted by means of instruments like laws, norms, and regulations. Binding norms guide the behavior of both governmental and non-governmental actors, and their compliance is guaranteed by a system of control and enforcement. Its rationale is deeply anchored in the legal and political principles guiding the functioning of modern states (Bouckaert et al. 2010).

In many cases, the classical hierarchical way of coordination is supplemented or even replaced by market-like instruments (Coase 1937; Williamson 1973) and network-based approaches (Kickert et al. 1997; Ouchi 1980; Rhodes 1997). Market-like modes of governance are based upon the idea that coordination can be realized by using market-like mechanisms: positive and negative incentives (like subsidies, contracts etc.) that change the benefits people attribute to certain actions and thus results into behavioral change. As Howlett (2009: 77) states, "the context, style, and substance of the marketplace has increasingly tended to infiltrate much of the policy design process in most countries in recent decades".

The network mode of governance focuses on mutual adjustment between mutually dependent actors. Government steering is based on designing and facilitating voluntary collaboration between actors who together define their aims and the way they want to realize them jointly (Kickert 1993; Koppenjan and Klijn 2015). The latter two modes of governance thus attempt to develop alternatives for the use of regulatory means, enabling government to suffice 
with a strategy which entails less intervention from the government side, a trend often described as 'governing without government' (Davies 2002; Rhodes 1997).

There are two other modes of governance we would like to add, as they are distinctive in terms of which mechanisms are used to realize coordination. A fourth mode of governance is based upon the idea that citizens and stakeholders have self-organizing capacities (Boonstra and Boelens 2011; Van Meerkerk et al. 2018). In this mode of governance, coordination is believed to be more effective if the government keeps its hands off and leaves it to spontaneous (bottom-up) actions of actors who are themselves able to create order due to their selforganizing capacity. In this mode of governance, governments thus have to abstain from intervention, facilitate room for people's creative ideas, and remove barriers. Only a limited facilitative role for governments is deemed necessary (Edelenbos et al. 2016).

The second addition has to do with governance based upon communication (Alexander 1995; Bekkers 2017; Lascoumes and Le Gales 2007). In this mode of governance, actors are given information about the problem, with illustrations of possible solutions (best practices), as well as tools and techniques for how to approach the issue. This mode of governance thus relies upon ideas of communicative steering, the sermon as policy instrument (BemelmansVidec et al. 2011). These five modes are displayed in Table 1. We do not aim to present a new typology or classification, but aim to structure the scholarly debate about governance and to subsequently use these forms in our analysis.

All types of governance or steering are deemed difficult, as resources are widely dispersed among actors and actors have different agendas and problem perceptions. As a result, modern societies are highly complex and government sectors are fragmented and difficult to understand and steer due to many interdependencies (Teisman et al. 2009). Moreover, governments do not have the necessary resources, capacity, and means to steer society in the way they prefer (Klijn and Teisman 2004). As a consequence, governments are bound to long policy design processes, with iterative steps, in which they design the policy instrument mix for the issues they want to influence.

\section{The governance of climate adaptation governance-a contested issue}

All of the aforementioned modes of governance are present in the literature on climate change governance (see for example Biesbroek et al. 2010; Broto and Bulkeley 2013; Mees et al. 2014). One of the most striking differences exists between authors who ask governments to restrain from intervention in this domain versus authors who plea for a strong, regulatory

Table 1 Modes of governance

\begin{tabular}{|c|c|}
\hline $\begin{array}{l}\text { Regulatory } \\
\text { governance }\end{array}$ & $\begin{array}{l}\text { 3ased on mandatory rules and regulations, whereby the government uses its legal } \\
\text { powers and superior position to enforce behavior. }\end{array}$ \\
\hline Network governance & $\begin{array}{l}\text { Based on the joint goal determination, combined use of resources, and coordinated } \\
\text { actions in cooperation with mutually dependent parties. }\end{array}$ \\
\hline Market governance & $\begin{array}{l}\text { Based on economic principles such as price mechanisms. Behavior is steered with price } \\
\text { incentives or by making the market responsible for making the necessary investments. }\end{array}$ \\
\hline $\begin{array}{l}\text { Communicative } \\
\text { governance }\end{array}$ & $\begin{array}{l}\text { Based on giving information, sharing good examples, highlighting high-profile } \\
\text { examples, and developing tools and knowledge that other parties can use to take } \\
\text { action themselves. }\end{array}$ \\
\hline Self-governance & $\begin{array}{l}\text { Based on self-steering capacity of actors to adjust their behavior and to look for } \\
\text { solutions to social problems. This process can be facilitated by government, but starts } \\
\text { bottom-up. }\end{array}$ \\
\hline
\end{tabular}


approach. The former believe in the power of spontaneous adaptation while the latter opt for planned adaptation (Cannon and Müller-Mahn 2010; Smit et al. 2000). Sometimes, those who opt for planned adaptation strongly plea for a regulatory approach because of the saliency of the topic, which is based on strict norms that guarantee that necessary actions are taken by a specifically mandated lead actor (Lazarus 2008). At the same time, authors (Camacho 2009) emphasize that - due to the infancy of the policy field - regulatory actions are still to be altered, as the policy field and its respective challenges are constantly changing. However, there are also many authors who argue that adaptation has to be based upon the collaborative effort of public, private, and societal actors, and measures are multifold and multifaceted. Some emphasize the value of "spreading the word," creating climate awareness and communication about the impact and strategies to deal with climate change (McCrum et al. 2009). Part of this mode of governance involves disseminating knowledge about best practices, making tools and techniques available, co-creating in urban labs, awarding champions and fostering learning processes (Collins and Ison 2009; Nevens et al. 2013). Simultaneously, financial incentives and other forms of market governance are deemed useful (Linnerooth-Bayer and Hochrainer-Stigler 2015). For example, many authors discuss the role that insurance arrangements, seed-money, and subsidies can play in stimulating adaptation (cf. Botzen and Van Den Bergh 2008; Fankhauser et al. 1999). More generally, the role private actors can take in adaptation is frequently discussed, especially with regard to the question of how responsibilities between public and private actors can be distributed (Mees et al. 2013; Tompkins and Eakin 2012).

This article aims to contribute to the debate on the governance of climate adaptation by investigating the opinions of Dutch stakeholders in this field. This study adds to the literature on the governance of climate adaptation, by enriching it with a more systematic and comparative investigation of the various modes of governance and focusing on practitioners' arguments for opting for one governance mode or another. In this era in which the role of government is heavily discussed and policy solutions are created in complex governance processes, the question is whether governance choices are legitimate and fit non-government actors, as they have the power to alter local circumstances and share their opinion in the climate adaptation debate. To understand the governance preferences on climate adaptation in the Netherlands, it is important to understand the context of the current debate on adaptation in this country.

\section{Climate adaptation governance in the Netherlands}

In 2008 the Dutch government installed a second Delta Committee. This committee presents key proposals annually in September to address climate change in the flood-prone Netherlands. One of the proposals that year was to install a Delta Commissioner. The Delta Commissioner is responsible for drafting the yearly Delta Program, which describes the aim to safeguard the Netherlands against the consequences of climate change.

The Delta Commissioner devoted his time to preparing five directional norms in the first years, the so-called Delta Decisions. One of these decisions was to implement climateresilience measures ranging from new norms for flood-risk safety, fresh water availability, and measures to deal with climate adaptation, especially related to drought, heat stress, water nuisance, and mitigating the consequences of floods. The risk of flooding by the rivers or from the sea is deeply engrained in the Dutch common awareness; thus, it was not difficult to come 
up with new norms for flood risk management. A much more passive attitude exists regarding other climate-related measures (Biesbroek et al. 2011). The other measures of this program are largely based upon the idea that local and regional governments, as well as private actors, and citizens have to be informed, inspired, and stimulated (through communicative governance) to both raise "climate awareness" and to implement adaptation measures. Most of the regional and local organizations feared the costs of additional responsibilities on this issue. Second, a preliminary evaluation (de Graaff et al. 2017) revealed that it was questionable whether this approach would be effective in order to realize the ambition of making the Netherlands climate-proof by 2050 .

In 2016, a mid-term review of this program showed that little progress was made and that many actors would prefer a more powerful and well-enforced approach in order to warrant progress. At the same time, some actors did not see any reason to alter the governance mode. It became clear that there was a deep controversy about how to foster and accelerate climate change adaptation. Hence, in this paper, we focus on this controversy to understand and unravel the different viewpoints prevalent among non-governmental stakeholders, to see which dominant and minority viewpoints hold true.

\section{Q methodology as a way to study preferred governance approaches to climate adaptation}

Q methodology was invented by William Stephenson (Brown 1993; Stephenson 1935). It is a method to study significantly different viewpoints within a given population, about a particular topic. The number of Q methodological studies is still scarce; however, for our study, this method was particularly useful. Contrary to mainstream statistical analyses - which are essentially item-analyses that correlate different items - Q methodology is geared towards correlating patterns of thought of the respondents, and respondents are the "variables" (Watts and Stenner 2012). Respondents reveal their viewpoints by sorting statements, and those who sort particular statements in a similar fashion have comparable views. Respondents who sort statements completely different disclose significantly different viewpoints. By means of factor analyses, one ends up with clusters, which reflect the majority and minority viewpoints in the debate on climate adaption (Watts and Stenner 2012). We chose this method over more traditional methods (e.g., interviews and surveys) as it provides insight into the viewpoints and how they differ on particular issues. This is useful to analyze, as such differences are proven to be the cause of inertia and non-implementation of policy, especially on climate adaptation (Hobson and Niemeyer 2011; Živojinović and Wolfslehner 2015, p. 1080). Q methodology also received its critiques. It is sometimes said to be overly descriptive, instead of explanatory (Ramlo and Newman 2011, p. 180), and respondents have to sort too many statements, which makes the distinction between statements too fine (McKeown and Thomas 2013).

The set of statements of a Q methodological study can be designed in many different ways. We followed three steps. First, the rule of thumb is that the set should be representative for the current debate on the topic (Watts and Stenner 2012). In order to safeguard this representativeness, we conducted 50 exploratory interviews among non-governmental actors, involved in and implementing the Delta program. In the interviews, we asked their opinions on the current governance approach regarding adaptation, and their wishes for the future approach (see Appendix 1). Second, from these interviews, we derived 200 literal statements. We removed 
statements that had the same meaning and rephrased unclear statements. We chose oftmentioned statements that are salient for the debate in the community and that reflect the whole breadth of the discussion within this community. We used a discourse matrix (see Table 2), like Dryzek and Berejikian (1993), to ensure the statements reflect both the different governance styles and elements of the current governance and preferred future governance approach. By working this way, we attained 25 statements. The numbers refer to the statements in Table 7. Third, the statements were piloted among five experts in the field. Afterwards, statements were again rephrased and more clearly articulated.

Subsequently, a survey was distributed online via PoetQ (Jeffares and Dickinson 2016) to a total of 726 non-governmental stakeholders from November 2016 to January 2017. This survey was part of an evaluation of the 'Deltaprogramma Ruimtelijke Adaptatie' (Delta Program on Spatial Adaptation) which set the joint ambition: "state, provinces, municipalities and water boards in the Netherlands will be as climate-proof and water-robust as possible in 2050, and will bear in mind - in case of landscape and urban (re) developments - that no extra risk of water and nature damage and casualties arise to the extent that is reasonably achievable. This climate-proof and water-robust mindset will be part of the recurrent policies and actions of these parties by 2020 at the latest". Deltares (the third author is employed by this organization), an independent institute for applied research in the field of water and subsurface, was commissioned to execute the evaluation and administers a mailing list of actors involved in the Delta Program on Spatial Adaptation. These respondents are stakeholders, implementing and advocating for adaptation measures in the following domains: drought, heat stress, water nuisance, and mitigating the consequences of floods. The respondents were asked to rank-order 25 statements on a scale from "does not reflect my opinion" to "reflects my opinion" in a normal distribution (see Fig. 1).

After five reminders, a total of 119 respondents finished the survey (response rate 16\%). After removing the governmental actors, we obtained a dataset of 98 non-governmental stakeholders. In Q methodological approaches, a response of less than or equal to the number of statements and four or five people defining each anticipated viewpoint is considered adequate (McKeown and Thomas 2013). In the descriptive questions, we asked for the repondents' organization of origin: private actors, knowledge institutions, and non-profit organizations. Table 3 displayes the respondents' organizations of origin.

Table 2 Discourse matrix, based on Dryzek and Berejikian (1993)

\begin{tabular}{llllll}
\hline & $\begin{array}{l}\text { Communicative } \\
\text { governance }\end{array}$ & $\begin{array}{l}\text { Regulatory } \\
\text { governance }\end{array}$ & $\begin{array}{l}\text { Market } \\
\text { governance }\end{array}$ & $\begin{array}{l}\text { Self- } \\
\text { governance }\end{array}$ & $\begin{array}{l}\text { Network } \\
\text { governance }\end{array}$ \\
\hline $\begin{array}{l}\text { Current practice: What is } \\
\text { dominant? }\end{array}$ & 1 & 2 & 3 & 4 & 5 \\
$\begin{array}{l}\text { I Current practice: is it } \\
\text { effective? }\end{array}$ & 6 & 7 & 8 & 9 & 10 \\
$\begin{array}{l}\text { II Current practice: what should } \\
\text { be changed? }\end{array}$ & 11 & 12 & 13 & 14 & 15 \\
$\begin{array}{c}\text { Future: what is needed to reach } \\
\text { the 2050 goals? }\end{array}$ & 16 & 17 & 18 & 19 & 20 \\
$\begin{array}{c}\text { Future I: what desired for the } \\
\text { future? }\end{array}$ & 21 & 22 & 23 & 24 & 25 \\
\hline
\end{tabular}




\begin{tabular}{|c|c|c|c|c|c|c|}
\hline-3 & -2 & -1 & 0 & 1 & 2 & 3 \\
\hline 1 & 2 & 3 & 4 & 5 & 6 & 7 \\
\hline \multirow[t]{6}{*}{8} & 9 & 10 & 11 & 12 & 13 & 14 \\
\hline & \multirow[t]{5}{*}{15} & 16 & 17 & 18 & 19 & \\
\hline & & 20 & 21 & 22 & & \\
\hline & & & 23 & & & \\
\hline & & & 24 & & & \\
\hline & & & 25 & & & \\
\hline
\end{tabular}

Fig. 1 Sorting grid

\section{Results}

Using KenQ analysis, a Web Application for Q Methodology by Prof. Shawn Banasick, ${ }^{1}$ we analyzed the data stemming from our 98 respondents. A typical Q sort analysis procedure starts with correlating all the Q-sorts. KenQ then helps to indicate the commonalities in the dataset and subsequently identifies the major clusters. This is called "factor extraction" and is achieved by a centroid analysis. We first retrieved seven centroid factors, and kept only three factors for rotation and applied Varimax rotation. The choice to retrieve only three factors was based on multiple iterative steps. First of all, the unrotated factor matrix showed only three factors with two (or more) pure loadings (Watts and Stenner 2012). Factors 4, 5, 6, and 7 had less than two pure loadings. Pure loadings are respondents that significantly load on one particular factor. However, in the first instance, when using a significance threshold of 0.01 , the factors were highly intercorrelated. We solved this - although the factors are still correlated (see Table 8) - by raising the significance threshold to 0.001 before flagging a certain respondent: $3.29 \times(1 / \sqrt{2} 2)=0.658$ (Van Exel and De Graaf 2005; Watts and Stenner 2012). The cumulative explained variance of the unrotated factors is $47 \%$.

Each factor will be explained in detail (see also Table 9). To interpret the factors that resulted after the analysis, we looked at three types of statements:

1. Characterizing statements placed on the extreme end of the poles: -3 and 3

2. Distinguishing statements which significantly different from other factors

3. Consensus statements which do not differ greatly in position when looking at the different factors

On the basis of the statements, and comments of respondents, the researchers reconstructed the viewpoints and gave every perspective an appropriate label.

\subsection{Viewpoint 1: make adaptation a formal obligation}

The first factor accounts for $34 \%$ of the total variance in the dataset (unrotated factor) and can therefore be called the dominant viewpoint (12\% after varimax rotation). Table 4 presents the

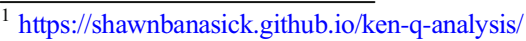


Table 3 Organization of origin

Private actors: constructors, grid operators, other

Knowledge institutions: universities, colleges, advisory boards and consultants $\quad 55$

Non-profits: NGOs, housing associations

statements which are scored highly and are significantly different when compared with the other factors. If we look into the distinguishing statements, respondents agree most with statements that describe the regulatory governance style, and mostly disagree with the statements describing communicative governance. In the future, a mixed approach-between regulatory governance, and sanctions - is necessary according to them: "especially because companies and citizens have to invest in climate adaptation solutions, they will not be so eager to do so" (Respondent 93, university, economics and respondent 73, consultancy flood risk).

This viewpoint underscores that part of the community disagrees with soft steering, as it led to the current partial adaptation (statement 21). Creating "buzz" words (statement 11 ) is not the right strategy, according to them. At the moment, the responsibilities are sometimes too unclear (statement 7). Respondents who load high on this viewpoint favor a clear framework, however "with latitude for citizens and companies to implement

Table 4 Distinguishing statements for factor 1

\begin{tabular}{|c|c|c|c|c|}
\hline $\begin{array}{l}\text { Statement } \\
\text { number }\end{array}$ & Statement & $\begin{array}{l}\text { Place } \\
\text { in grid }\end{array}$ & Significance & $\begin{array}{l}\text { Governance } \\
\text { perspective }\end{array}$ \\
\hline 12 & $\begin{array}{l}\text { For the implementation of climate resilience, it is essential } \\
\text { that goals and obligations are clearly laid down. }\end{array}$ & 3 & & Regulatory \\
\hline 17 & $\begin{array}{l}\text { In order to achieve the } 2050 \text { targets, enforceable legal } \\
\text { obligations and standards are required, including } \\
\text { sanctions in the event of default. }\end{array}$ & 3 & & Regulatory \\
\hline 23 & $\begin{array}{l}\text { Non-governmental actors have to bear the consequences } \\
\text { themselves if their investments are not climate friendly. }\end{array}$ & 2 & $*$ & Market \\
\hline 14 & $\begin{array}{l}\text { Parties confronted with the consequences of climate } \\
\text { change will automatically seek for ways to cope with } \\
\text { them. }\end{array}$ & 2 & * & Self-governance \\
\hline 9 & $\begin{array}{l}\text { As the urgency increases, parties will automatically adjust } \\
\text { their behavior and take measures }\end{array}$ & 1 & $*$ & Self-governance \\
\hline 7 & $\begin{array}{l}\text { The current policy is ineffective, because it is unclear who } \\
\text { is responsible for what. }\end{array}$ & 1 & $*$ & Regulatory \\
\hline 15 & Joint effort is the key to realizing climate resilience. & 0 & & $\begin{array}{l}\text { Network } \\
\text { governance }\end{array}$ \\
\hline 13 & $\begin{array}{l}\text { The central government must financially support } \\
\text { municipalities, water boards, and provinces to make } \\
\text { investments in favor of climate resilience. }\end{array}$ & -1 & * & $\begin{array}{l}\text { Market } \\
\text { governance }\end{array}$ \\
\hline 11 & Climate resistance must become a "buzz word." & -2 & & $\begin{array}{l}\text { Communicative } \\
\text { governance }\end{array}$ \\
\hline 22 & $\begin{array}{l}\text { As climate resilience is always about local customization, } \\
\text { it is not desirable to work with generic standards. }\end{array}$ & -3 & $*$ & $\begin{array}{l}\text { Regulatory } \\
\text { governance }\end{array}$ \\
\hline 21 & $\begin{array}{l}\text { Soft management (via images, stories and sharing of } \\
\text { experiences) remains the most desirable way to work } \\
\text { on climate resilience in the long run. }\end{array}$ & -3 & & $\begin{array}{l}\text { Communicative } \\
\text { governance }\end{array}$ \\
\hline
\end{tabular}

Statements are significant at $P<.05$

*Significance at $P<.01$ 
efficient and effective measures which fit the local context" (respondent 93, university, economics). One respondent points towards the word "norm". He states that standards can be generic and he would prefer a framework with guidelines, that provides clarity and promotes the speed of implementation (Respondent 43, NGO, technical union). These respondents call the idea that adaptation measures need "local customization", an excuse not to proceed to action (statement 22): "I do not understand why climateproofing is always about local customization! Without clear goals and obligations, actors do little and 2050 is approaching faster than you might think. Without real commitment, nothing changes fundamentally!" (respondent 6, university, urban planning).

According to some respondents who load high on this factor, parties have to be confronted with the consequences of climate change. If they are not confronted, they will not take action (respondent 52, NGO and respondent 73, consultancy flood risk). People who are confronted with climate adaptation will have to search for ways to adapt (statement 14), and otherwise will have to face costs (by the government) if their efforts and investments are not climate-proof (statement 23).

This fact or shows a viewpoint in the debate, that favors enforcing norms and goals to reach the climate objectives (statements 12 and 17). In this viewpoint, propositions that fit with the theoretical perspective of regulatory governance are particularly relevant. This viewpoint is strongly present in the current debate on climate change adaptation in the Netherlands. It is represented by authoritative institutes like the Scientific Council of the Government (Faber et al. 2016). In 2016, the Netherlands Environmental Assessment Agency emphasized that - without more clear policy guidelines-major opportunities to realize adaptation measures by coupling them with investments in spatial planning would be missed. However, at the national policy level, hesitance towards a more obligatory approach is still strong. This is clear from the Implementation Program of the National Adaptation Strategy 2018-2019 which has a strong focus on raising awareness, fostering an intergovernmental dialog and sharing best practices.

\subsection{Viewpoint 2: foster co-creation and self-organization}

The second viewpoint shows a mix of self-governance and communicative governance statements (see Table 5). The factor accounts for $6 \%$ of the total variance (unrotated factor, and $13 \%$ after varimax rotation) in the dataset and is therefore less prevalent compared to factor 1 .

These respondents think that responsibilities are currently clear (statement 7) but think these responsibilities do not lead to the necessary adjustments (statement 9). Therefore, they advocate for a mindset change for the future: "there is a senseless legal and financial shear process going on at the moment: who should be doing what tasks and with what competence. However, this discussion is endless. I see more opportunities if making payback-effects and possibilities visible, with best practices and experts" (respondent 69, foundation, soil). Providing "best practices" is seen in this perspective as an important basis for steering (statement 16 and 21). Whenever financial incentives are mentioned, these are seen as positive incentives to get parties in motion: "as long as everyone work within his own 'silo', nothing will happen, and we will waste a lot of funds. If you frame this problem as a multifaceted issue, we can partner up and show an end result which is useful and also financially attractive. However, there needs to be a starting point, which the national government should create (financially)" (respondent 79, NGO, community 
Table 5 Distinguishing statements for factor 2

\begin{tabular}{|c|c|c|c|c|}
\hline $\begin{array}{l}\text { Statement } \\
\text { number }\end{array}$ & Statement & $\begin{array}{l}\text { Place } \\
\text { in grid }\end{array}$ & Significance & $\begin{array}{l}\text { Governance } \\
\text { perspective }\end{array}$ \\
\hline 24 & $\begin{array}{l}\text { We must try to realize climate adaptation in the future in a } \\
\text { smart way and without many additional costs, by } \\
\text { integrated thinking and working. }\end{array}$ & 3 & $*$ & Self-governance \\
\hline 16 & $\begin{array}{l}\text { To achieve the } 2050 \text { goals, much more knowledge and } \\
\text { examples need to be shared. }\end{array}$ & 3 & $*$ & Communicative \\
\hline 15 & Joint effort is the key to realizing climate resilience. & 2 & * & Self-governance \\
\hline 12 & $\begin{array}{l}\text { For the implementation of climate resilience, it is essential } \\
\text { that goals and obligations are clearly laid down. }\end{array}$ & 1 & & Regulatory \\
\hline 21 & $\begin{array}{l}\text { Soft management (via images, stories, and sharing of } \\
\text { experiences) remains the most desirable way to work on } \\
\text { climate resilience in the long run. }\end{array}$ & 1 & $*$ & Communicative \\
\hline 14 & $\begin{array}{l}\text { Parties confronted with the consequences of climate } \\
\text { change will automatically seek for ways to cope with } \\
\text { them. }\end{array}$ & -1 & & Self-governance \\
\hline 18 & $\begin{array}{l}\text { The achievement of the } 2050 \text { targets requires the } \\
\text { development of financial and economic instruments. }\end{array}$ & -1 & & $\begin{array}{l}\text { Market } \\
\text { governance }\end{array}$ \\
\hline 7 & $\begin{array}{l}\text { The current policy is ineffective, because it is unclear who } \\
\text { is responsible for what. }\end{array}$ & -2 & * & Regulatory \\
\hline 9 & $\begin{array}{l}\text { As the urgency increases, parties will automatically adjust } \\
\text { their behavior and take measures. }\end{array}$ & -3 & & Self-governance \\
\hline
\end{tabular}

$P<.05: *$ significance at $P<.01$

based). By framing issues as an integrated policy problem, it is possible to provide opportunities for different stakeholders to see the added value from collaboration (statement 24). Water, green spaces, and dikes have many functions and meanings; by connecting these functions in a new way, more than climate-proofing can be achieved (e.g. environmental quality) (respondent 84, consultancy spatial planning). One of the respondents notes for instance that a better connection between spatial policy and longterm flood risk management generates more opportunities for other actors to get involved (respondent 65, consultancy spatial planning).

An important facet is the emphasis these respondents place on the self-organizing capacity of parties. Joint energy is the engine behind achieving climate-proofing, according to the respondents (statement 15). One of the respondents indicates that this is, on the one hand is unavoidable because non-government parties are the largest land/real estate owners. On the other hand, there is "a safety paradox." The national government and the water boards ensure that citizens feel safe behind the dikes, so citizens and other non-governmental organizations are not stimulated to actively engage themselves to take action regarding climate change (respondent 65, consultancy spatial planning). Respondents who load high on this factor agree that by allowing parties to experience the urgency and challenges themselves, they will be encouraged to take initiatives to meet the targets from 2050. Stakeholders of municipalities and water boards must be stimulated and facilitated by provinces and central government to develop spatial plans with integrated added value that can also be quantified by sector and by stakeholder (respondent 69 , foundation, soil).

At this moment, in the Netherlands this position is most strongly articulated by the national policy community on climate adaptation. It is especially the dominant policy belief of the 
National Ministry and fits also in the current policy paradigm as it relates to planning and spatial development which is more and more based upon principles of mutual agreement, customization, and giving space to base local decisions on local considerations (as is exemplified in the new Environmental Act).

\subsection{Viewpoint 3: be clear about responsibilities}

The third viewpoint is a mixed model; respondents most strongly agree with the statements referring to regulatory and market governance (see Table 6). The factor accounts for $7 \%$ of the total variance (unrotated factor, $23 \%$ after varimax rotation) in the dataset. According to these respondents, there are currently too few financial incentives to achieve climate resilience (statement 8) and the effectiveness of the policy leaves something to be desired, because it is not clear who is responsible for what (statement 7). The respondents indicate that they disagree with statements related to communicative, network and self-governance.

For the implementation of climate resilience, it is essential for these respondents that goals and obligations are clearly defined (statement 12). Those goals and obligations should however not be enforced. At the same time, the respondents state that the government should certainly not have a wait-and-see attitude: "A government can be expected to operate pro-actively. Behavioral change requires time, effort and leadership and apathy is deadly! (literally and figuratively). The government should take matters into its own hands, and make sure that competences lies where an effect can be gained". (Respondent 78, consultancy water related, also: respondent 39, university spin-off

Table 6 Distinguishing statements for factor 3

\begin{tabular}{|c|c|c|c|c|}
\hline $\begin{array}{l}\text { Statement } \\
\text { number }\end{array}$ & Statement & $\begin{array}{l}\text { Place } \\
\text { in grid }\end{array}$ & Significance & $\begin{array}{l}\text { Governance } \\
\text { perspective }\end{array}$ \\
\hline 7 & $\begin{array}{l}\text { The current policy is ineffective, because it is unclear who } \\
\text { is responsible for what. }\end{array}$ & 3 & $*$ & Regulatory \\
\hline 12 & $\begin{array}{l}\text { For the implementation of climate resilience, it is essential } \\
\text { that goals and obligations are clearly laid down. }\end{array}$ & 3 & & Regulatory \\
\hline 8 & $\begin{array}{l}\text { There are currently too few financial incentives to achieve } \\
\text { climate resilience. }\end{array}$ & 2 & $*$ & Market \\
\hline 10 & $\begin{array}{l}\text { Many promising measures for achieving climate resilience } \\
\text { are not realized, because parties are unable to look } \\
\text { beyond their own turf. }\end{array}$ & 2 & $*$ & Network \\
\hline 15 & Joint effort is the key to realizing climate resilience. & 0 & & Network \\
\hline 1 & $\begin{array}{l}\text { At present, parties are mainly motivated to work on } \\
\text { climate resilience, on the basis of good examples. }\end{array}$ & 0 & & Communicative \\
\hline 9 & $\begin{array}{l}\text { As the urgency increases, parties will automatically adjust } \\
\text { their behavior and take measures. }\end{array}$ & -1 & & Self-governance \\
\hline 14 & $\begin{array}{l}\text { Parties confronted with the consequences of climate } \\
\text { change will automatically seek for ways to cope with } \\
\text { them. }\end{array}$ & -2 & & Self-governance \\
\hline 21 & $\begin{array}{l}\text { Soft management (via images, stories, and sharing of } \\
\text { experiences) remains the most desirable way to work on } \\
\text { climate resilience in the long run. }\end{array}$ & -2 & & Communicative \\
\hline 25 & $\begin{array}{l}\text { It is an art in itself not to take matters into your own hands } \\
\text { as a government, even if the effects of climate change } \\
\text { become clearer. }\end{array}$ & -2 & $*$ & Self-governance \\
\hline
\end{tabular}

$P<.05: *$ significance at $P<.01$ 
environment). At the moment, climate policy often takes form along the line of institutionalized interest groups, according to this cluster of respondents. There is no real shared ownership (respondent 60, consultancy natural built assets). If the competences are clearer, climate adaptation will become mainstream and thus an integral part of daily operations. One of the respondents explains: "It then can be included in the planned spatial investments, for example in the case of new constructions or urban renewal" (respondent 64, consultant organization advice).

One could see the ideas advocated by this factor assubsidiarity; respondents want to place competences where they fit and belong. However, these respondents see that this subsidiarity is not working for some stakeholders, as costs are borne by parties who do not see direct benefits: what are the incentives for them to cover these costs? A respondent explains: "developers build according to legal requirements and therefore need hard steering; there is a great demand for housing and cheap and fast construction without taking into account climate resilience" (respondent 60, consultancy natural built assets). Therefore, the national government must financially support municipalities, water boards, and provinces to make the necessary investments for climate-proofing (statement 13). The respondents who load on this factor advocate for dedicated budgets: "dedicated budgets function as a catalyst, and finally lead to good policy!" (Respondent 78 , consultancy water related).

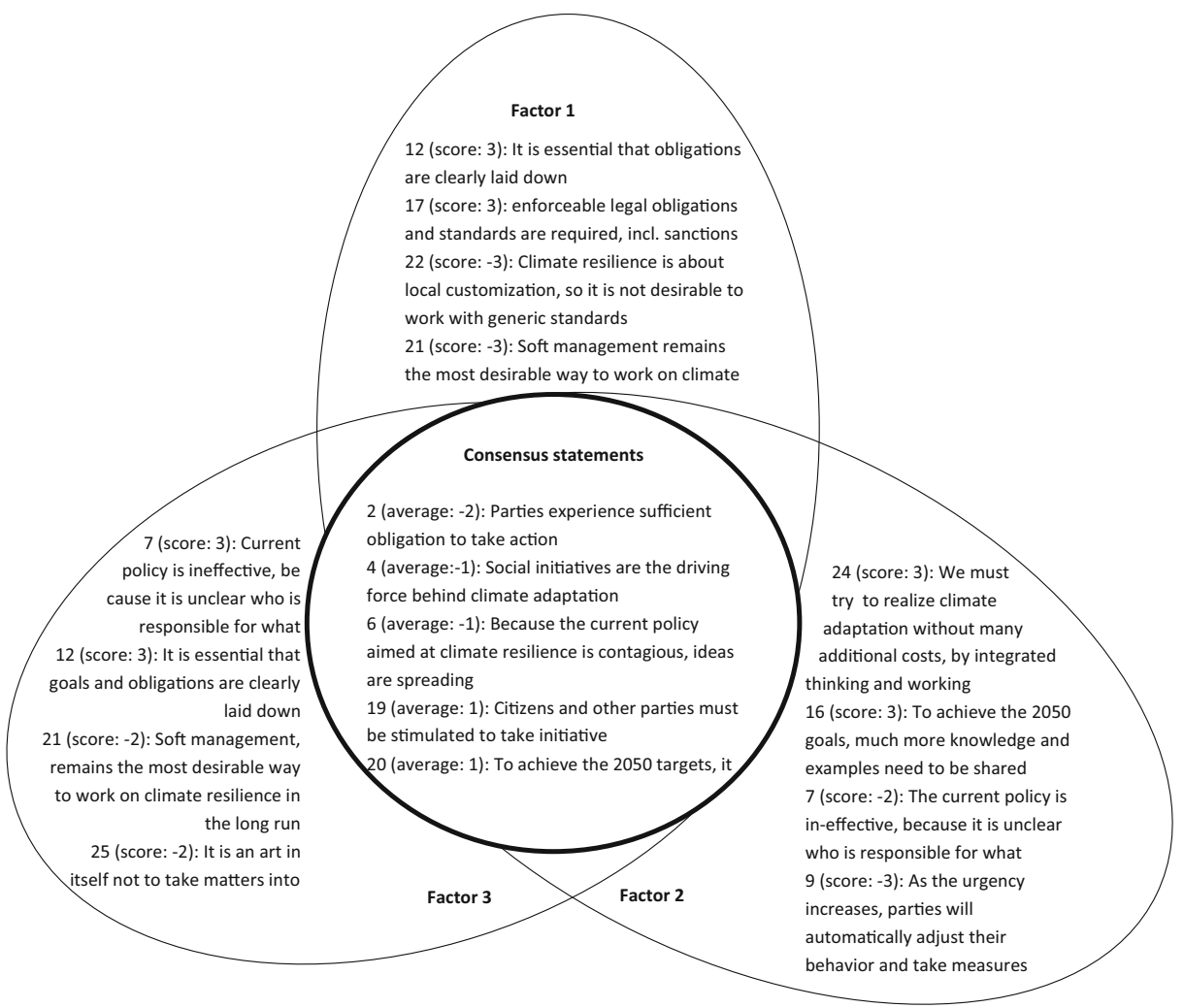

Fig. 2 The extreme elements of the factors and the consensus statements 


\section{Discussion}

Before we reflect upon the three perspectives, it is useful to show on which statements there is consensus (see middle of Fig. 2).

All respondents disagree with the statement that parties experience enough obligation to do something about climate change (statement 2). This statement is placed on -2 and -3 on the grid, in all perspectives, and therefore, this is a shared feeling in this community. Furthermore, a huge point of agreement is that actors have to - more than ever before - take joint initiatives and collaborate in the future (statement 20). Hence, the calls for a less voluntary approach and for a more intense collaboration go hand-in-hand. That raises the interesting question of metagovernance: how to combine a more hierarchical with a more collaborative network approach and to come to a more synergistic interplay (Pahl-Wostl 2019)? Actors also agree upon but are more neutral about another statement: whether societal initiatives are the driving force behind climate adaptation (statement 4). They disagree with the fact that the current policy aimed at climate resilience is contagious (statement 6) and agree that actors should be motivated to take initiative and responsibility (statement 19).

When we delve further into the three perspectives and confront them with the current debate on the governance of climate adaptation, we can see interesting similarities. The first perspective, a plea for a stronger role of the government, is also resembled by recent studies on the governance of climate adaptation. Bednar et al. (2019) concluded, based upon a comparative analysis of two Canadian provinces, that a more hierarchical mode of governance is necessary to overcome implementation barriers in climate adaptation.

The second perspective on "spontaneous" adaptation (and governance as "stimulating and fueling" in combination with communicative and self-governance) is quite popular by governments who hesitate to take decisive action in a time of climate skepticism, high uncertainty, and low public awareness (Biesbroek et al. 2010; Ford et al. 2011). It is also popular among scientists who see bottom-up initiatives as a welcome additional source of organizing capacity (Duijn et al. 2019; Mees et al. 2013).

The third perspective reflects the more academic debate about fairness, equity, and distributive justice in relation to climate change adaptation (Adger 2006; Klinsky and Dowlatabadi 2009). This body of literature stipulates the challenge to agree upon a set of incentives and provisions that make actors who have a stake or who can be held responsible for causing or increasing risks responsible for taking action. Although there is strong support among many stakeholders to implement a system of rules and incentives, it is also controversial, especially because the whole Dutch system of flood protection is based upon the idea of public responsibility to take the necessary measures.

Finally, the largest area of disagreement is on the topic of soft management, the idea that climate adaptation awareness should be spread through images, stories, and sharing best practices (statement 21). Additionally, the discourses show major disagreement on whether it matters to point out and make responsibilities clearer, in terms of effectiveness (statement 7). In the paragraphs above, we showed that some of the respondents think that the responsibilities are already clear but that some actors do not take the necessary steps to implement measures. Next, the respondents disagree on whether actors who are confronted with the saliency (statement 9) and the consequences (statement 14) of climate change will spontaneously adapt. Lastly, the respondents disagree about the extent to which the government should intervene and force actors to adapt (statement 25). 


\section{Conclusion}

The Dutch debate on how to govern climate adaptation in an effective way shows the intricate and controversial character of the issue. Our Q methodological study illustrates the fierce and significant viewpoints of stakeholders about the right mode of governance. Overall, this study proves that the non-governmental respondents think that parties do not experience enough saliency in the community to take action regarding climate change, which is a clear consensus point among the stakeholders. This view is echoed in many scientific contributions that state that the current worldwide governance approach is too non-committal and thus ineffective (Fischer 2017; Hulme 2009; Lazarus 2008).

However, on how to govern the issue, respondents' opinions differ significantly. The strongest factor resembles the regulatory governance style. This group states that actors do not feel the urgency to adapt at present. Rather, they advocate for a strong national government that establishes clear rules so that actors who do not adhere would be financially sanctioned. We can conclude that there is a substantial group of stakeholders who want to go beyond the non-commitment and make climate adaptation a formal obligation.

This perspective strongly contrasts with the second perspective, which focus upon the power of self-organization. This perspective on spontaneous adaptation (and governance as stimulating and fueling in combination with communicative and self-governance) is quite contrary to the plea for more decisive action. Stakeholders who hold this view see the responsibility for adaptation as a shared responsibility. However, they also are convinced that governments have to invest in informing stakeholders, increasing expertise and facilitating fruitful partnerships. Focusing upon a more facilitative role thus does not imply leaning backwards.

The third group takes a position in the middle and focuses upon the right conditions for the governance of climate adaptation. They are quite positive about a stronger and more decisive government approach, which makes this position comparable to the first one. However, the third group sees it as a necessary precondition to effectively distribute responsibilities and obligations in order to achieve cost-effective and fair policies. They want to safeguard that each actor is held accountable for taking action in its own jurisdiction. This perspective shows strong resemblance with the literature on climate adaptation fairness, distributive justice and the search for normative principles to organize adaptation in a legitimate way (Adger 2016; Hartzell-Nichols 2011; Page 2008).

Interestingly, the results from our Q methodological study strongly resembles the academic controversy about the best way to realize climate adaptation. In this study we see a large difference between the explained variance in the unrotated and rotated factors. Moreover, the factors can be considered moderately correlated. Hence, we can conclude that there is consensus mainly about the first perspective, and perspective two and three nuance this perspective. These perspectives are consequently of interest to understand this heavily debated theme. In the academic debate, proponents of a more hierarchical governance style can be found alongside supporters of a more networked, collaborative style and those who emphasize the importance of legitimacy, fairness, and thus the need for principles that do justice to the peculiarities of climate adaptation. The same positions are clear from the Q-sort analysis. However, in all three groups, we witness a preference for more decisive action in light of expected climate change in the near future. Even 
those who aim to foster co-creation and self-organization emphasize the need for greater commitment. In addition, those who underline the need for clear responsibilities embed their argument in a discourse in which the need for timely action gets a central function. An increased sense of urgency thus results in a plea for more decisive action, although this does not signify that the government has to act in a traditional, government-centric way (similar point in Adger et al. 2013).

\section{Policy implications}

Our results illustrate the complex character of the governance of climate adaptation and the difficulties to organize it in a legitimate way. Not only the question of whether adaptation is necessary is being debated. In addition, the question of how to organize it is a delicate one. Our results indicate that the perceptions on appropriate ways of organizing adaptation are highly divergent. That also means that governments have a double difficulty. They have to guarantee support for putting adaptation on their agenda, but they also have to find out what mode of governance is seen as legitimate and suitable.

Our study reveals the multiplicity in governance preferences among nongovernmental stakeholders. For policy-makers, acknowledging this multiplicity is highly important. Using the width of possible modes can help governments to change deeply engrained governance routines (e.g. in the Netherlands the preference for regulatory governance in water governance, using standards based on calculated risks).

The results of our study show highly different but not incompatible preferences. This forms a strong argument to think about the governance mix (Howlett et al. 2017) that can be used to enhance the legitimacy and effectiveness of the governance of adaptation and which is able to avoid policy traps in the long term (Nair and Howlett 2016; Rogge and Reichardt 2016). The question about legitimacy thus goes beyond establishing the most effective mode of governance. It has much more to do with which governance mix is able to deal with the capricious nature of climate change and which has the best fit with society, groups of stakeholders, or regions. As our research shows, the respondents prefer not only more decisive action from the governmental side, they also emphasize fairness and justice and ask for a facilitating government that enables spontaneous action from the bottom up. Exploring how these perspectives can be combined in a powerful mixed mode is - given the controversial but urgent need for adaptation - a pressing design challenge.

\section{Appendix 1. Topic list}

\section{PART 1: Introduction}

1. What are you mainly concerned with in the area of climate adaptation?

2. To what extent is there a sense of urgency within your organization for these tasks?

3. Are you familiar with the objectives of the Delta Decision on Climate adaptation?

a. To what extent do these goals match your professional practice / your own goals? Inspiring? Feasible? Why? Examples?

b. What suggestions do you have for improvement? 


\section{PART 2: Instruments, approach, and results}

4. What instruments/resources do you use to achieve climate adaptation-related goals in your professional practice?

5. Did you use the instruments offered by the climate adaptation stimulation program?

6. Do you collaborate with "unusual" partners (other than central government or decentralized government) in achieving climate adaptation? With whom? How did that come about?

7. To what extent are tasks/division of responsibilities and authorities clear and sufficient with regard to the realization of climate adaptation?

8. What are the three most important factors that help you/your organization to achieve climate adaptation goals and which three factors hinder? Why?

9. What results (from instruments, processes, measures, etc.) from your own professional practice do you see in the field of climate adaptation? Examples?

\section{PART 3: Conditions: policy programs and broader social context}

10. Which policy programs interfere (advantageously or disadvantageously) with climate adaptation in your practice?

11. Which social themes interfere (social and economic developments) with climate adaptation in your professional practice / your organization?

\section{PART 4: Towards 2020 and 2050}

12. In general: What is going well? What not?

13. What goals do you see for 2020? And 2050? Is it possible to achieve those goals/the goals of the Delta Decision on Climate adaptation under current institutional conditions (financing, regulations, procedures, etc.)?

If not:

a. Which adjustments do you think are necessary?

b. Which "building blocks" (factors/conditions) are needed?

14. What could be strengthened in your own organization?

\section{Appendix 2}




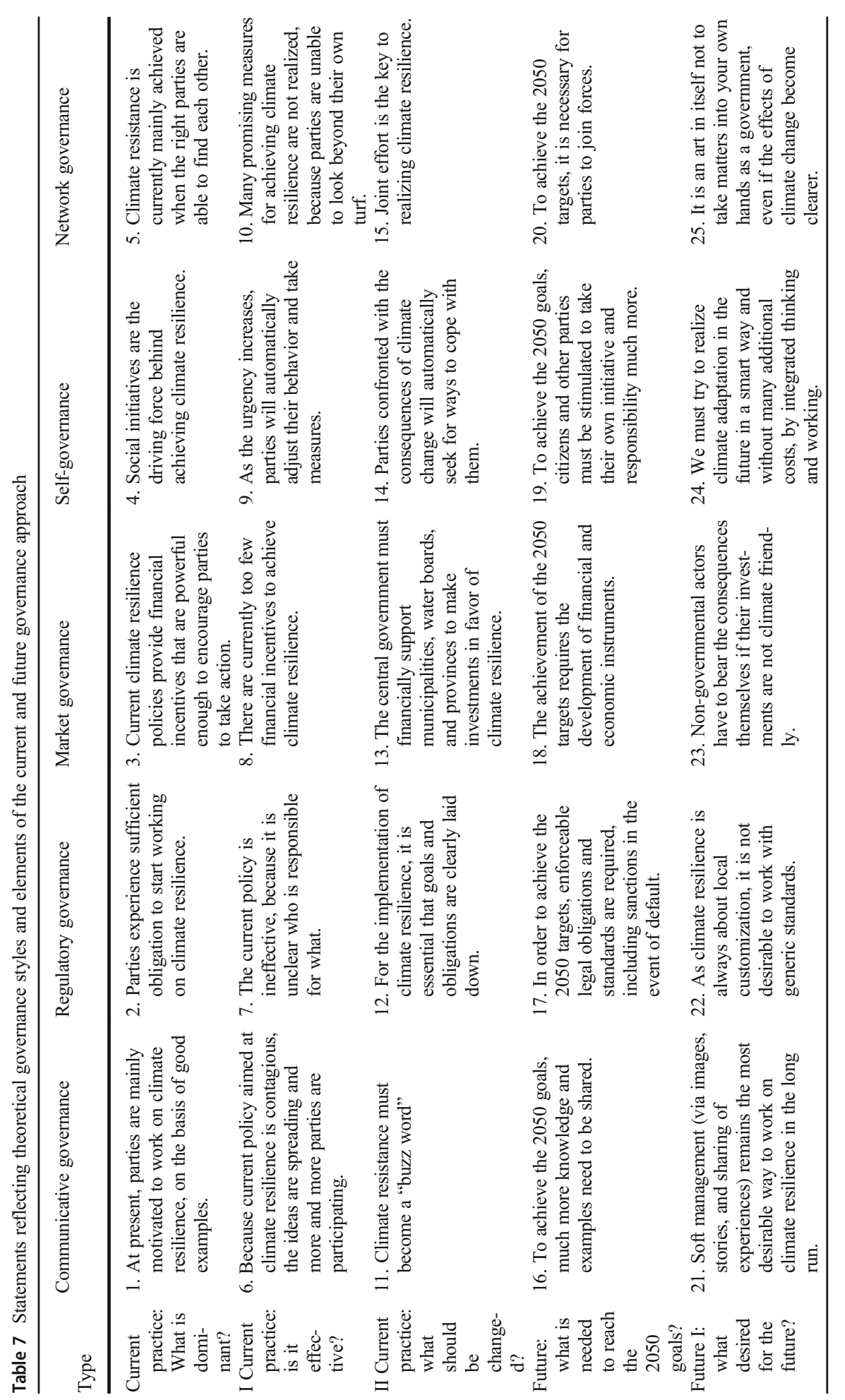




\section{Appendix 3}

Table 8 Factor correlations

Factor score correlations

\begin{tabular}{llll}
\hline & Factor 1 & Factor 2 & Factor 3 \\
\hline Factor 1 & 1 & 0.2638 & 0.4498 \\
Factor 2 & 0.2638 & 1 & 0.5249 \\
Factor 3 & 0.4498 & 0.5249 & 1 \\
\hline
\end{tabular}

\section{Appendix 4}

Table 9 Factor characteristics

\begin{tabular}{lllc}
\hline & Factor 1 & Factor 2 & Factor 3 \\
\hline No. of defining variables & 5 & 3 & 16 \\
Avg. Rel. Coef. & 0.8 & 0.8 & 0.8 \\
Composite reliability & 0.952 & 0.923 & 0.985 \\
S.E. of factor Z-scores & 0.219 & 0.277 & 0.122 \\
\hline
\end{tabular}

Open Access This article is licensed under a Creative Commons Attribution 4.0 International License, which permits use, sharing, adaptation, distribution and reproduction in any medium or format, as long as you give appropriate credit to the original author(s) and the source, provide a link to the Creative Commons licence, and indicate if changes were made. The images or other third party material in this article are included in the article's Creative Commons licence, unless indicated otherwise in a credit line to the material. If material is not included in the article's Creative Commons licence and your intended use is not permitted by statutory regulation or exceeds the permitted use, you will need to obtain permission directly from the copyright holder. To view a copy of this licence, visit http://creativecommons.org/licenses/by/4.0/.

\section{References}

Adger WN (2006) Vulnerability. Glob Environ Chang 16(3):268-281

Adger WN (2016) Place, well-being, and fairness shape priorities for adaptation to climate change. Glob Environ Chang 38:A1-A3

Adger WN, Quinn T, Lorenzoni I, Murphy C, Sweeney J (2013) Changing social contracts in climate-change adaptation. Nat Clim Chang 3(4):330-333

Alexander ER (1995) How organizations act together, interorganizational coordination in theory and practice. Gordon and Breach Publishers, Luxembourg

Alford J, Head BW (2017) Wicked and less wicked problems: a typology and a contingency framework. Polic Soc 36(3):397-413 
Bednar D, Henstra D, McBean G (2019) The governance of climate change adaptation: are networks to blame for the implementation deficit? J Environ Policy Plan 21(6):702-717

Bekkers VJJM (2017) Beleid in beweging. Achtergronden, benaderingen, fasen en aspecten van beleid in de publieke sector. Boom Lemma uitgevers, Den Haag

Bemelmans-Videc M-L, Rist RC, Vedung EO (2011) Carrots, sticks, and sermons: Policy instruments and their evaluation, vol 1. Transaction Publishers

Biesbroek GR, Swart RJ, Carter TR, Cowan C, Henrichs T, Mela H et al (2010) Europe adapts to climate change: comparing national adaptation strategies. Glob Environ Chang 20(3):440-450

Biesbroek GR, Klostermann J, Termeer C, Kabat P (2011) Barriers to climate change adaptation in the Netherlands. Clim Law 2(2):181-199

Boonstra B, Boelens L (2011) Self-organization in urban development: towards a new perspective on spatial planning. Urban Res Pract 4(2):99-122

Botzen WJW, Van Den Bergh JCJM (2008) Insurance against climate change and flooding in the Netherlands: present, future, and comparison with other countries. Risk Anal 28(2):413-426

Bouckaert G, Peters GB, Verhoest K (2010) The coordination of public sector organizations: shifting patterns of public management. Palgrave Macmillan, Hampshire

Bovaird T, Löffler E (2009) More quality through competitive quality awards? An impact assessment framework. Int Rev Adm Sci 75(3):383-401

Broto VC, Bulkeley H (2013) A survey of urban climate change experiments in 100 cities. Glob Environ Chang 23(1):92-102

Brown SR (1993) A primer on Q methodology. Operant Subj Int J Q Methodol 16(3/4):91-138

Camacho AE (2009) Adapting governance to climate change: managing uncertainty through a learning infrastructure. Emory Law J 59:1

Cannon T, Müller-Mahn D (2010) Vulnerability, resilience and development discourses in context of climate change. Nat Hazards 55(3):621-635

Coase RH (1937) The nature of the firm. Economica 4(16):386-405

Collins K, Ison R (2009) Jumping off Arnstein's ladder: social learning as a new policy paradigm for climate change adaptation. Environ Policy Gov 19(6):358-373

Considine M (2001) Enterprising states: the public management of welfare-to-work. Cambridge University Press, Cambridge

Considine M, Lewis JM (1999) Governance at ground level: the frontline bureaucrat in the age of markets and networks. Public Adm Rev 59(6):467-480

Considine M, Lewis JM (2003) Bureaucracy, network, or enterprise? Comparing models of governance in Australia, Britain, the Netherlands, and New Zealand. Public Adm Rev 63(2):131-140

Davies JS (2002) The governance of urban regeneration: a critique of the 'governing without government' thesis. Public Adm 80(2):301-322

de Graaff R, Steegh J, Aerts M, van der Brugge R, van Buuren A, Dekker G et al (2017) Tussentijdse Evaluatie Ruimtelijke Adaptatie, Reflecteren en Inspireren. Eindrapport, Leiden

Dixon J, Dogan R (2002) Hierarchies, networks and markets: responses to societal governance failure. Adm Theory Prax 24(1):175-196

Dryzek JS, Berejikian J (1993) Reconstructive democratic theory. Am Polit Sci Rev 87(1):48-60

Duijn M, van Buuren A, Edelenbos J, van Popering-Verkerk J, Van Meerkerk I (2019) Community-based initiatives in the Dutch water domain: the challenge of double helix alignment. Int J Water Resour Dev 35(3):383-403

Edelenbos J, van Meerkerk I, Schenk T (2016) The evolution of community self-organization in interaction with government institutions: cross-case insights from three countries. Am Rev Public Adm 48(1):52-66

Faber AP, de Goede en MW (2016) Klimaatbeleid voor de lange termijn: van vrijblijvend naar verankerd, WRRPolicy Brief 5, Den Haag: WRR

Fankhauser S, Smith JB, Tol RSJ (1999) Weathering climate change: some simple rules to guide adaptation decisions. Ecol Econ 30(1):67-78

Fischer F (2017) Climate crisis and the democratic prospect: participatory governance in sustainable communities. Oxford University Press

Ford JD, Berrang-Ford L, Paterson J (2011) A systematic review of observed climate change adaptation in developed nations. Clim Chang 106(2):327-336

Hall CM (2011) A typology of governance and its implications for tourism policy analysis. J Sustain Tour 19(4 5):437-457

Hartzell-Nichols L (2011) Responsibility for meeting the costs of adaptation. Wiley Interdiscip Rev Clim Chang 2(5):687-700

Henstra D (2016) The tools of climate adaptation policy: analysing instruments and instrument selection. Clim Pol 16(4):496-521 
Hobson K, Niemeyer S (2011) Public responses to climate change: the role of deliberation in building capacity for adaptive action. Glob Environ Chang 21(3):957-971

Howlett M (2009) Governance modes, policy regimes and operational plans: a multi-level nested model of policy instrument choice and policy design. Policy Sci 42(1):73-89

Howlett M, Vince J, Del Río P (2017) Policy integration and multi-level governance: dealing with the vertical dimension of policy mix designs. Polit Gov 5(2):69

Huitema D, Adger WN, Berkhout F, Massey E, Mazmanian D, Munaretto S et al (2016) The governance of adaptation: choices, reasons, and effects. Introduction to the Special Feature. Ecol Soc 21(3)

Hulme M (2009) Why we disagree about climate change: understanding controversy, inaction and opportunity. Cambridge University Press

Jeffares S, Dickinson H (2016) Evaluating collaboration: the creation of an online tool employing Q methodology. Evaluation 22(1):91-107

Keast R, Brown K, Mandell M (2007) Getting the right mix: unpacking integration meanings and strategies. Int Public Manag J 10(1):9-33

Kickert WJM (1993) Complexity, governance and dynamics: conceptual explorations of public network management. In: Kooiman J (ed) Modern governance. Sage, London, pp 191-204

Klijn E-H, Teisman GR (2004) Strategies and games in networks. In: Kickert WJM, Klijn E-H, Koppenjan JFM (eds) Managing complex networks. Strategies for the public sector. Sage, London, pp 98-118

Klinsky S, Dowlatabadi H (2009) Conceptualizations of justice in climate policy. Clim Pol 9(1):88-108

Koppenjan J, Klijn EH (2015) Governance networks in the public sector. Routledge, London

Lascoumes P, Le Gales P (2007) Introduction: understanding public policy through its instruments - from the nature of instruments to the sociology of public policy instrumentation. Governance 20(1):1-21

Lazarus RJ (2008) Super wicked problems and climate change: restraining the present to liberate the future. Cornell Law Rev 94(5):1153-1233

Linnerooth-Bayer J, Hochrainer-Stigler S (2015) Financial instruments for disaster risk management and climate change adaptation. Clim Chang 133(1):85-100

Lowndes V, Skelcher C (1998) The dynamics of multi-organizational partnerships: an analysis of changing modes of governance. Public Adm 76(2):313-333

McCrum G, Blackstock K, Matthews K, Rivington M, Miller D, Buchan K (2009) Adapting to climate change in land management: the role of deliberative workshops in enhancing social learning. Environ Policy Gov 19(6):413-426

McKeown B, Thomas DB (2013) Q methodology, vol 66. Sage Publications

Mees HLP, Driessen PPJ, Runhaar HAC, Stamatelos J (2013) Who governs climate adaptation? Getting green roofs for stormwater retention off the ground. J Environ Plan Manag 56(6):802-825

Mees HLP, Dijk J, van Soest D, Driessen PPJ, van Rijswick MH, Runhaar H (2014) A method for the deliberate and deliberative selection of policy instrument mixes for climate change adaptation. Ecol Soc 19(2):58

Molenveld A, Verhoest K, Voets J, Steen T (2020) Images of Coordination: How Implementing Organizations Perceive Coordination Arrangements. Public Adm Rev 80(1):9-22

Nair S, Howlett M (2016) From robustness to resilience: avoiding policy traps in the long term. Sustain Sci 11(6): 909-917

Nevens F, Frantzeskaki N, Gorissen L, Loorbach D (2013) Urban transition labs: co-creating transformative action for sustainable cities. J Clean Prod 50:111-122

Ouchi WG (1980) "Markets, bureaucracies, and clans." Adm Sci Q 25(1)

Page EA (2008) Distributing the burdens of climate change. Env Polit 17(4):556-575

Pahl-Wostl C (2019) The role of governance modes and meta-governance in the transformation towards sustainable water governance. Environ Sci Pol 91:6-16

Powell WW (1990) Neither market nor hierarchy: network forms of organization. In: Staw BM, Cummings LL (eds) Research in organizational behavior, vol 12. JAI Press, Greenwich, pp 295-336

Ramlo SE, Newman I (2011) Q methodology and its position in the mixed- methods continuum. Operant Subj Int J Q Methodol 34(3):172-191

Rhodes RAW (1997) Foreword. In: Kickert WJM, Klijn E-H, Koppenjan JFM (eds) Managing complex networks: strategies for the public sector. Sage, London

Rogge KS, Reichardt K (2016) Policy mixes for sustainability transitions: an extended concept and framework for analysis. Res Policy 45(8):1620-1635

Salamon LM (2002) The new governance and the tools of public action: an introduction. In: Salamon LM (ed) The tools of government: a guide to the new governance. Oxford University Press, New York, pp 1-47

Smit B, Burton I, Klein RJT, Wandel J (2000) An anatomy of adaptation to climate change and variability. Clim Chang 45(1):223-251

Stephenson W (1935) Technique of factor analysis. Nature 136(3434):297 
Teisman G, Gerrits L, van Buuren A (2009) Managing complex governance systems - dynamics, selforganization and coevolution in public investments. Routledge, New York

Tenbensel T (2018) Bridging complexity theory and hierarchies, markets, networks, communities: a 'population genetics' framework for understanding institutional change from within. Public Manag Rev 20(7):10321051

Thompson G, Frances J, Levacic R, Mitchell J (1991) Markets, hierarchies and networks: the coordination of social life. Sage Publications Limited, London

Tompkins EL, Eakin H (2012) Managing private and public adaptation to climate change. Glob Environ Chang 22(1):3-11

Van Exel J, De Graaf G (2005) Q methodology : a sneak preview. Sociol Sci 2:1-30

Van Meerkerk I, Kleinhans R, Molenveld A (2018) Exploring the durability of community enterprises: a qualitative comparative analysis. Public Adm 96(4):615-667

Verweij M, Douglas M, Ellis R, Engel C, Hendriks F, Lohmann S et al (2006) Clumsy solutions for a complex world: the case of climate change. Public Adm 84(4):817-843

Voets J, Verhoest K, Molenveld A (2015) Coordinating for integrated youth care: the need for smart metagovernance. Public Manag Rev 17(7):981-1001

Watts S, Stenner P (2012) Doing Q methodological research: theory, method \& interpretation. Sage, London

Williamson OE (1973) Markets and hierarchies. Am Econ Rev 63(2):316-332

Williamson OE (1996) The mechanisms of governance. Oxford University Press, London

Živojinović I, Wolfslehner B (2015) Perceptions of urban forestry stakeholders about climate change adaptation a Q-method application in Serbia. Urban For Urban Green 14(4)

Publisher's note Springer Nature remains neutral with regard to jurisdictional claims in published maps and institutional affiliations. 